Author version: J. Foraminifer. Res.: 40(3); 2010; 220-230

\title{
Deciphering the Modern Calcification Depth of Globigerina Bulloides in the Southwestern Indian Ocean from its Oxygen Isotopic Composition
}

\author{
R. SARASWAT ${ }^{1,3}$ AND N. KHARE ${ }^{2}$ \\ ${ }^{1}$ Micropaleontology Laboratory, National Institute of Oceanography, Dona Paula, Goa- 403 004, India \\ ${ }^{2}$ Ministry of Earth Sciences, Block \#12, CGO Complex, Lodhi Road, New Delhi - 110 003, India \\ ${ }^{3}$ Correspondence author: E-mail: rsaraswat@nio.org; rs.niog@gmail.com
}

\begin{abstract}
The water depth at which the planktic foraminiferal species Globigerina bulloides calcifies its shell has been deciphered based on the oxygen isotopic composition of its shells in surface sediment samples collected from the southwestern Indian Ocean. The seawater temperature for water depths ranging from 0-200 $\mathrm{m}$ was estimated from $G$. bulloides $\delta^{18} \mathrm{O}$ by using various paleotemperature equations. Out of several paleotemperature equations, the one given by Epstein and others (1953) provided the best-fit results. Similarly, the estimated seawater salinity was calculated using the seawater $\delta^{18} \mathrm{O}$ calculated from $G$. bulloides $\delta^{18} \mathrm{O}$, and measured seawater temperature taken from the Levitus database. A comparison of seawater salinity and temperature estimated from G. bulloides $\delta^{18} \mathrm{O}$, with the measured seawater salinity and temperature at different water depths, shows that the calcification depth of $G$. bulloides varies latitudinally. From the equator to $\sim 15^{\circ} \mathrm{S}$, the calcification depth of G. bulloides was inferred to be $\sim 75 \mathrm{~m}$. Between $15^{\circ} \mathrm{S}$ and $\sim 43^{\circ} \mathrm{S}$, the estimated seawater temperature matched well with the seawater temperature at $\sim 200 \mathrm{~m}$ water depth, indicating that the G. bulloides calcification depth was comparatively deeper in this region. Farther south of $\sim 43^{\circ} \mathrm{S}$, however, the calcification depth appears to be considerably shallower than in the northern part of the study area. The comparison also showed that irrespective of latitudinal region, the estimated seawater temperature matches well with the seawater temperature during the austral spring season suggesting that G. bulloides is abundant at that time. The findings will help in paleoclimatic reconstruction studies based on characteristics of $G$. bulloides.
\end{abstract}




\section{INTRODUCTION}

The isotopic composition of foraminifera has been used extensively to infer paleoclimatic and paleoceanographic variations (Sen Gupta, 1991; Waelbroeck and others, 2005). The application of foraminiferal isotopic composition as a proxy for past climatic changes relies on the understanding of factors affecting the isotopic composition of foraminiferal tests (Bemis and others, 1998). Numerous field and laboratory culture studies have been carried out to understand the factors that affect the isotopic composition of certain benthic and planktic foraminiferal species (Bemis and others, 1998; Mulitza and others, 2003). These show that temperature, salinity, $\mathrm{pH}$, carbonate-ion concentration, productivity, presence and absence of symbionts, etc., are among the important factors that influence the isotopic composition of foraminiferal tests (see Bijma and others, 1999, for review). All these parameters vary with changing water depth and since planktic foraminiferal species have been reported to inhabit different depths in the oceans (Bé and Tolderlund, 1971), isotopic composition of different species provides information of the seawater characteristics at different depths. However, in order to infer water column characteristics from foraminifera, it is necessary to have precise information of the water depth inhabited by species whose characteristics are being used to infer past climatic and oceanographic changes. The depth habitat of foraminiferal species can be assessed based on plankton tow samples (Bé and Tolderlund, 1971). It has been reported, however, that planktic foraminiferal species migrate vertically in the water column during their life-span (Hemleben and Bijma, 1994). A comparison of seawater physico-chemical parameters estimated from the characteristics of foraminiferal species segregated from surface sediments with the independently measured physico-chemical parameters at different water depths can also provide information about the depth habitat of foraminiferal species. This can then help in generating better proxy information for foraminiferal characteristics to infer past water column conditions.

In this paper an attempt has been made to infer the depth habitat of the planktic foraminiferal species Globigerina bulloides d'Orbigny 1826. Specimens of the non-symbiotic planktic foraminiferal species G. bulloides proliferate in comparatively cold water $\left(0-27^{\circ} \mathrm{C}\right.$, peak abundance at $3-19^{\circ} \mathrm{C}[\mathrm{Bé}$ and Tolderlund, 1971]), and with high amounts of nutrients which leads to increased primary productivity. Previously, factors affecting the isotopic composition of G. bulloides, have been inferred from specimens collected from surface sediments and plankton tows, as well as laboratory culture studies (Spero and Lea, 1996; Bemis and others, 1998; Peeters and others, 2002). Subsequently, King 
and Howard (2005) carried out oxygen isotopic analysis on various planktic species, including $G$. bulloides, from sediment traps deployed in the Southern and Pacific oceans, to find out the applicability of various paleotemperature equations as well as the seasonality in the factors affecting the stable isotopic composition.

The knowledge of factors influencing the abundance and shell chemistry of G. bulloides has lead to its extensive application in paleoclimatic reconstruction. Temporal changes in the abundance and isotopic characteristics of $G$. bulloides have been used as an indicator of upwelling changes in the Indian Ocean, (Prell, 1984; Anderson and Prell, 1993; Naidu and Malmgren, 1996; Conan and Brummer, 2000; Gupta and others, 2003); however, the various factors that might affect the isotopic composition of $G$. bulloides are still debated (Peeters and others, 2002). The uncertainty probably arises because of the limited information available about the depth at which $G$. bulloides calcifies its test. Part of the isotopic disequilibrium of $G$. bulloides tests has been attributed to seawater carbonate chemistry and ontogenetic changes (Bemis and others, 1998, 2000, 2002). Inferring the calcification temperature from the isotopic composition of G. bulloides, Peeters and others (2002) deduced that G. bulloides precipitates most of its test just below the deep chlorophyll maximum but above the main thermocline, leading to the offset between the sea surface temperature and the calcification temperature of G. bulloides. However, based on the plankton tow samples collected from both the Indian and Atlantic oceans, Bé and Tolderlund (1971) inferred that $G$. bulloides does not have any preferred depth habitat. In view of these contradictory reports, better information is needed on the depth at which G. bulloides incorporates its isotopic signature.

In this study, we infer the calcification depth of $G$. bulloides from its oxygen isotopic composition using specimens collected from surface water in a transect across the southwestern Indian Ocean. Our approach involves estimating temperature and salinity from the oxygen isotopic composition of the tests, then comparing the results with the CTD-measured and Levitus temperature and salinity parameters at different depths.

\section{OCEANOGRAPHIC SETTING}

The southwestern Indian Ocean is an integral part of both the Indian and Southern oceans (Fig. 1). The Indian Ocean experiences seasonally reversing surface currents with a characteristic change in the equatorial currents. The westward-flowing North Equatorial Current (NEC) is prominent in January 
and March under the influence of the northeast monsoon. It runs as a narrow current from the Malacca Strait to southern Sri Lanka, where it bends southward between $2^{\circ} \mathrm{S}-5^{\circ} \mathrm{N}$ in the region between $60-75^{\circ} \mathrm{E}$. The South Equatorial Current (SEC) occupies the region south of $8^{\circ} \mathrm{S}$ and receives water from the Indonesian Throughflow as well as water subducted in the southeastern subtropical Indian Ocean. The Equatorial Counter Current (ECC) runs between these westward flows. During July-September, the entire region north of $5^{\circ} \mathrm{S}$ is dominated by the eastward flow of the southwest-monsoon current. The transition between the onset of the northeast monsoon and the end of the southwest monsoon is again characterized by the equatorial jet. This change in the circulation, north of the equator is largely controlled by the prevailing winds (Schott and McCreary, 2001). The southwestern Indian Ocean is also characterized by the presence of shallow salinity-maximum water, which forms in the subtropical gyre of the southern Indian Ocean as Subtropical Subsurface Water (SSW). The SSW occupies depths of 100-250 m (Swallow and others, 1988). Similarly, South Indian Ocean circulation is characterized by a subtropical anticyclonic gyre. The gyre's northern boundary, between $10-20^{\circ} \mathrm{S}$, is the westward-flowing South Equatorial Current (SEC). which the African subcontinent deflects poleward as the Agulhas Current until a part of it joins the eastward-flowing Antarctic Circumpolar Current (ACC) and then completes the loop by flowing equatorward as the West Australian Current. Stramma (1992) identified the South Indian Ocean Current (SOC) lying at or near the Subtropical Front (STF) that is located at $\sim 40^{\circ} \mathrm{S}$ in the central South Indian Ocean. The STF separates the warmer and saltier water of the subtropics from the cold, fresh, nutrient-rich subantarctic water.

The South Equatorial Current (SEC), mainly sourced from the Indonesian Throughflow and Equatorial Counter Current (ECC), comprises the surface waters in the equatorial and southern part of the study area. Part of the northern region of the study area receives Equatorial Current surface waters that are partially derived from the Bay of Bengal region. Similarly, the southernmost part of the southwestern Indian Ocean receives surface waters from the subtropical gyre and subtropical current, which originate from the South Indian Ocean Current that flows north of the Circumpolar Current (Tomczak and Godfrey, 2003).

Subtropical Surface Water with relatively high salinity occurs in the Indian Ocean region west of $45^{\circ} \mathrm{E}$ and is carried farther north by internal circulation. In the tropics, low-salinity Tropical Surface Water overlies the Subtropical Surface Water (Toole and Warren, 1993). Tropical Surface Water has also been reported in the southwestern Indian Ocean (Grundlingh and others, 1991). The source of shallow waters occupying the upper thermocline in the Indian Ocean include: 1) Arabian Sea water, 
formed in the northern Arabian Sea during the northeast monsoon season; 2) Subtropical subsurface water, formed in the subtropical gyre of the southern hemisphere; 3) Bay of Bengal water, formed in the northern Bay of Bengal by river runoff and precipitation; and 4) Persian Gulf Water (Schott and McCreary, 2001). Tritium data show that Indian Ocean surface water north of $40^{\circ} \mathrm{S}$ (except that in the Bay of Bengal) and down to the thermocline are mainly the result of net inflow from the Indonesian Throughflow (Fine, 1985). You and Tomczak (1993) also showed that thermocline waters in the equatorial Indian Ocean are the result of mixing of Indonesian Throughflow waters (ITF) from the east with Indian Ocean waters from the north and south. Part of the ITF water gets incorporated in the northward-flowing arm of the South Equatorial Current and then upwells in the region of Somalia. Chlorofluorocarbon ages of the seawater show that the Southeast Indian Ocean is the source for thermocline waters in the northern Indian Ocean (Fine and others, 2008). The seasonally reversing monsoon can affect waters to depths of $500 \mathrm{~m}$ (Colborn, 1975).

During transition periods between monsoons, the mixed-layer depth is relatively shallow in the northern part of the study area as a result of strong eastward surface jets (Rao and others, 1989). In general, mixed-layer thickness is controlled by wind velocity. Anilkumar and others (2006) reported that the thickness of the mixed layer was $10-56 \mathrm{~m}$ at $31-39^{\circ} \mathrm{S}$, and was as thick as $104 \mathrm{~m}$ farther south. Similarly, the thermocline was also shallower $(40-150 \mathrm{~m})$ in the northern part (31-39 $\mathrm{S})$ compared to the frontal region $\left(60-100 \mathrm{~m}\right.$ at $\left.40-43^{\circ} \mathrm{S}\right)$, whereas it was indistinguishable in polar waters (south of $\left.45^{\circ} \mathrm{S}\right)$.

\section{MATERIALS AND METHODOLOGY}

For stable isotopic analysis, $8-10$ tests of Globigerina bulloides in the $250-355 \mu \mathrm{m}$ size range (sieve size) were picked from 19 surface sediment samples (Fig. 1, Table 1). In view of size-dependent ontogenetic isotopic fractionation (Bemis and others, 1998, 2000; Peeters and others, 2002), efforts were made to further narrow the size range but limited availability of specimens made it difficult. Surface sediment (top few $\mathrm{cm}$ ) samples were taken from gravity- and piston-core tops and grab samples. The presence of live (rose-Bengal stained) calcareous and agglutinated benthic foraminifera confirmed that the sample was surface sediment (further sampling details have been discussed by Khare and Chaturvedi, 2006). 
Stable isotopic analyses were performed at the Alfred Wegener Institute for Polar and Marine Research (Bremerhaven) using a Finnigan MAT 251 isotope-ratio gas mass spectrometer coupled to an automatic carbonate preparation device (Kiel I) and calibrated via NBS 19 to the PDB scale. The values are given in $\delta$-notation versus VPDB (Vienna Pee Dee Belemnite). Precision of oxygen isotope measurements based on repeat analyses of a laboratory standard over a one year period was better than $0.09 \%$ for oxygen.

In order to estimate the calcification temperature from the stable oxygen isotopic composition of G. bulloides, a regression equation was derived between $\delta^{18}$ Osw and salinity by plotting the $145 \delta^{18} \mathrm{Osw}$ and salinity values between $5^{\circ} \mathrm{N}-60^{\circ} \mathrm{S}$ and $35-100^{\circ} \mathrm{E}$ available in the global seawater oxygen-isotopic composition database (Fig. 2; Schmidt and others, 1999). The relationship between seawater salinity and $\delta^{18}$ Osw was found to vary latitudinally (Fig. 3, Table 2).

The latitudinal plot of seawater salinity and $\delta^{18}$ Osw shows an almost uniform relationship between $0-30^{\circ} \mathrm{S}$ (Fig. 3A-C). Therefore, an average value based on the plot of all the data points between $0-30^{\circ} \mathrm{S}$ was used (Fig. 3D). The relationship was different at $30-40^{\circ} \mathrm{S}$ (Fig. 3E) and $40-50^{\circ} \mathrm{S}$ (Fig. 3F); hence, appropriate equations were used to estimate $\delta^{18}$ Osw for these latitudes. The relationship between seawater salinity and $\delta^{18} \mathrm{Osw}$ at latitudes farther south was not clear. Since, only one station from the present study lies south of $50^{\circ} \mathrm{S}$, the $\delta^{18} \mathrm{Osw}$ for this location was estimated based on the regression equation derived for $40-50^{\circ} \mathrm{S}$. It should be noted that the relationship was developed based on the salinity and $\delta^{18}$ Osw estimates available for surface water, and that the same relationship might not hold for subsurface water. Using the regression equations (Fig. 3), $\delta^{18}$ Osw at water depths of $0,50,75,100,150$, and $200 \mathrm{~m}$, at the sample locations were calculated. In order to calculate the $\delta^{18} \mathrm{Osw}$ for the sample locations, salinity values in the Levitus database (Levitus and Boyer, 1994) were used. From the $\delta^{18} \mathrm{Osw}$ calculated for the different water depths at sample locations and measured $\delta^{18}$ Oc, seawater temperature was estimated by using four paleotemperature equations (Table 3): 1) that given by Bemis and others (1998) for 12-chambered G. bulloides shells (equation 1); 2) the revised paleotemperature equation of Bemis and others (2000) for 11-chambered shells (equation 2); 3) the paleotemperature equation given by Epstein and others (1953), based on calcite precipitation in mollusks (equation 3); and 4) the inorganic calcite precipitation equation (equation 4) of Kim and O'Neil (1997).

Seawater temperatures at different water depths estimated by these different paleotemperature equations were plotted against the annual average seawater temperature taken from the Levitus database (Levitus and Boyer, 1994) and onboard CTD measurements (Fig. 4). To check the seasonality in 
seawater temperature estimated by using $\delta^{18} \mathrm{Oc}$, seasonal seawater temperature was estimated from the seasonal $\delta^{18} \mathrm{Osw}$, which was estimated from the Levitus seasonal salinity. However, except for a few locations at certain water depths, this estimated seasonal seawater temperature was nearly same during all seasons. This similarity in estimated seasonal seawater temperature is due to very little seasonal change in seawater salinity.

For all four equations, $\delta^{18}$ Osw was brought to the $\delta^{18}$ Oc scale by correcting it by a factor of 0.20 for equation 3 and by 0.27 for equations 1,2 and 4 . The temperatures estimated by using equations 3 and 4 were more comparable with the measured and Levitus seawater temperatures.

In order to estimate salinity from the oxygen isotopic composition of G. bulloides, the $\delta^{18} \mathrm{Osw}$ was calculated by using $\delta^{18} \mathrm{O}$ G. bulloides and Levitus temperature at different depths at the sample locations, and the paleotemperature equation given by Epstein and others (1953; Table 3, equation 3). The following solution of the quadratic equation was used to estimate the stable isotopic composition of the seawater:

$$
\delta^{18} O s w=\delta^{18} O c-\{(16.5-T) / 4.3\}
$$

From the $\delta^{18}$ Osw thus calculated for different depths at respective locations, salinity was estimated by using the regression equations mentioned above. The estimated seawater salinity at different depths was then plotted against the Levitus salinity and onboard CTD measurements (Fig. 5). In view of the seasonal changes in the abundance of $G$. bulloides, estimated seawater temperature was then compared with seasonal seawater temperature at different depths (Fig. 6).

\section{RESULTS}

As expected, the CTD-measured seawater temperature and Levitus temperature are similar (Fig. 4). Seawater temperature estimated by the paleotemperature equation of Epstein and others (1953; Table 3, equation 3) matches best with Levitus and CTD measured seawater temperature. Earlier, King and Howard (2005) also found that this equation gave the most precise seawater temperature estimates from $\delta^{18}$ Oc. Therefore, only the relationship between seawater temperature estimated by using the paleotemperature equation of Epstein and others (1953) with the measured and Levitus seawater temperature is discussed in detail. The seawater temperature estimated from $\delta^{18}$ Oc and $\delta^{18}$ Osw are offset 
from that measured by as much as $\sim 12^{\circ} \mathrm{C}$ at $200 \mathrm{~m}$ at a few locations, and this decreases to $<1^{\circ} \mathrm{C}$ at 150 $\mathrm{m}$ at many of the locations in the southern part of the study area. For depths of 100, 150, and $200 \mathrm{~m}$, the estimated values are warmer than those measured by $2-10^{\circ} \mathrm{C}$ for the tropical region $\left(0-20^{\circ} \mathrm{S}\right)$ but revert to the general trend of being colder than measured at higher latitudes (Fig. 4). Estimated and measured seawater temperature values are comparable at water depths of 100, 150, and $200 \mathrm{~m}$ in extreme southern latitudes $\left(40-55^{\circ} \mathrm{S}\right)$.

Estimated salinity is more saline at 0 and $50 \mathrm{~m}$ depth than at 150-200 $\mathrm{m}$ water depths. The difference in the estimated and measured salinity values is greatest in the northern part of the study area $\left(0-20^{\circ} \mathrm{S}\right)$. The maximum offset $(\sim 11)$ of estimated salinity (less saline) is observed at $150 \mathrm{~m}$ and $200 \mathrm{~m}$ water depths at $0-20^{\circ} \mathrm{S}$. At $75 \mathrm{~m}$ depth the estimated salinity approaches that measured, between $0-20^{\circ} \mathrm{S}$, but at mid-high latitudes remains $\sim 5 \mathrm{psu}$ more saline, but again approaches the measured

salinity even farther south. In general, the estimated salinity south of $40^{\circ} \mathrm{S}$ approaches the measured salinity.

A better match is found between the estimated and seasonal seawater temperature. The estimated seawater temperature matches well with the measured seawater temperature at $\sim 75 \mathrm{~m}$ depth, between the equator, and $\sim 15^{\circ} \mathrm{S}$. At 15 to $\sim 43^{\circ} \mathrm{S}$, the estimated seawater temperature is comparable with the seawater temperature at $\sim 200 \mathrm{~m}$ depth. South of $\sim 43^{\circ} \mathrm{S}$, the estimated seawater temperature is nearly the same as the seawater temperature at 0-50 m depth. The comparison also showed that, irrespective of latitude, the estimated seawater temperature best matches the seawater temperature during the austral spring season (Fig. 6).

\section{DISCUSSION}

The southwestern Indian Ocean is a comparatively less-studied part of the Indian Ocean as far as foraminiferal studies are concerned. Understanding the factors influencing the shell chemistry of selected foraminiferal species from this region will enhance applications of foraminiferal characteristics to reconstruct paleoclimatic and paleoceanographic history of this region. This study was undertaken to determine the water depth inhabited by the planktic foraminiferal species Globigerina bulloides in this part of the Indian Ocean.

Since temperature and salinity are among the significant factors that influence foraminiferal shell chemistry, they can be estimated from the isotopic composition of the test and be used to infer the depth 
at which the shells calcify. A strong influence of seawater temperature on $\delta^{18} \mathrm{O}$ of $G$. bulloides was reported by Durazzi (1981). We note that the estimated and measured seawater temperatures show a latitudinal match, particularly at $\sim 75 \mathrm{~m}$ water depth in the northern part of the southwestern Indian Ocean. These findings support the notion that G. bulloides is a comparatively deep-dwelling plankton, probably inhabiting the water above the thermocline. The thermocline in the studied area has been reported to vary within the range of 75-150 m (Anilkumar and others, 2005). Cayre and Bassinot (1998) also concluded that $G$. bulloides lives at a depth of $\sim 75 \mathrm{~m}$ in the Indian Ocean, based on comparison of seawater $\delta^{18} \mathrm{O}$ at different depths calculated from seawater temperature and salinity. Similarly, based on the abundant $(>50 \%)$ presence of total standing population at different depths, Kahn and Williams (1981) showed that G. bulloides preferentially lives at 75-100 m water depth. The deeper depth habitat of $G$. bulloides in southern high latitudes is further supported by earlier studies, wherein maximum abundance of planktic foraminifera during summer was reported at 50-90 m water depth (Kopczynska and others, 2001). In the southern part, the estimated seawater temperature is similar to the seawater temperature in comparatively deeper water $(\sim 200 \mathrm{~m})$. This probably indicates the influence of the deeper thermocline on $\delta^{18} \mathrm{O} G$. bulloides in this area (Anilkumar and others, 2006). Chen and others (1998) have also shown a negative correlation of G. bulloides with SST and positive correlation with depth of the thermocline in the South China Sea. The findings are further supported by the views expressed by Peeters and others (2002), that the seawater temperature estimated from the oxygen isotopic composition of $G$. bulloides is lower than the surface seawater temperature by about $1.3 \pm 0.9^{\circ} \mathrm{C}$. Similarly Deauser and others (1981) noted that $\delta^{18} \mathrm{O}$ G. bulloides differs from the seasonal sea surface temperature. King and Howard (2005), however, suggested a surface to near-surface dwelling depth for G. bulloides, based on the stable oxygen isotopic analysis of the specimens collected from core tops and sediment traps deployed in the Pacific sector of the Southern Ocean. The difference is probably due to the different equation $\left(\delta^{18}\right.$ Owater $=0.66 \times$ Salinity -22.6$)$ that King and Howard $(2005)$ used to estimate the seawater temperature from the $\delta^{18}$ Oc.

In the extreme southern part of the study area, shallow $(0-50 \mathrm{~m})$ seawater temperatures correspond well with the estimated seawater temperature. Change in the dwelling depth of G. bulloides from deeper water in low latitudes to shallow water in high latitudes has also been reported by Durazzi (1981). Mortyn and Charles (2003) also reported that the depth of maximum abundance of G. bulloides varies from location to location. A slight mismatch at latitudes farther south probably results from the seasonally changing relationship between $\delta^{18}$ Osw and salinity. This mismatch might result from the 
change in habitat depth of G. bulloides, from well below the thermocline to surface during intervals of upwelling, as estimated from its stable oxygen isotopic composition (Sautter and Thunel, 1991). The offset might also indicate the influence of certain vital factors other than temperature and salinity. Thus, it is inferred that the dwelling depth of G. bulloides varies latitudinally in the southwestern Indian Ocean. Core-top studies of isotopic composition of other foraminiferal species from the Indian Ocean have also suggested geographic variations in calcification depth (Williams and Healy-Williams, 1981).

Estimated seawater temperature at different depths is invariably similar to measured seawater temperature during the austral spring season, irrespective of depth, indicating that the greater abundance of G. bulloides during the spring is due to the increased availability of nutrients. Peak spring flux of $G$. bulloides in the Southern Ocean has also been reported by King and Howard (2005). However, Deauser and others (1981) deployed sediment traps in the deep Sargasso Sea, and found G. bulloides peaked in abundance both during winter and spring.

The latitudinal effect in the estimated and measured temperature and salinity plots roughly indicates the depth of the mixed layer and thermocline in the southwestern Indian Ocean. Thus, seawater circulation patterns transporting water to and from the study area influence the biological and physicochemical characteristics of its seawater. Such circulation-influenced changes in seawater are, in turn, reflected in the shell chemistry of the G. bulloides.

\section{CONCLUSIONS}

Globigerina bulloides retrieved in sediment samples collected from 19 sites in the southwestern Indian Ocean between $10-60^{\circ} \mathrm{S}$ enabled us to compare measured seawater temperature and salinity with $\delta^{18} \mathrm{Oc}$ estimates in order to decipher its calcification depth and check the suitability of various paleotemperature equations. Among various equations, of Epstein and others (1953) yielded estimates that best approach measured seawater temperature. Based on the similarities observed between estimated and measured seawater temperature and salinity, we conclude that the calcification depth of $G$. bulloides varies latitudinally in the southwestern Indian Ocean. A comparatively shallower calcification depth is observed in the northern and extreme southern part of the study area, while the calcification depth increases to $\sim 200 \mathrm{~m}$ between $\sim 15-43^{\circ} \mathrm{S}$. A seasonally changing abundance of $G$. bulloides is also inferred by the calcification temperature at almost all latitudes matching well with seawater temperature 
during the austral spring season. In the southwestern Indian Ocean, the calcification depth of $G$. bulloides roughly corresponds with the thermocline depth.

\section{ACKNOWLEDGMENTS}

The authors are thankful to Dr. S.R. Shetye, the Director and Dr. R. Nigam, National Institute of Oceanography, Goa, for the support and permission to publish the results. Duly acknowledged is the help from Prof. A. Mackensen and his research staff at the Alfred Wegener Institute for Polar and Marine Research (Germany) for carrying out the isotopic analysis. The manuscript has greatly benefited by the comments and suggestions of Dr. K.L. Finger (University of California, Berkeley), Dr. H. Spero (University of California, Davis), Dr. Penelope Cooke (University of Waikato), Prof. Will Howard (University of Tasmania), and Dr. Bruce Hayward (GeoMarine Reseach, Aukland). We are also grateful to Dr. Vikrant Jain, Delhi University, for assistance with the quadratic equation.

\section{REFERENCES}

Anderson, D. M. and Prell, W. L., 1993, A $300 \mathrm{kyr}$ record of upwelling off Oman during the late Quaternary: Evidence of the Asian southwest monsoon: Paleoceanography, v. 8, p. 193-208.

Anilkumar, N., Dash, M. K., Luis, A. J., Ramesh Babu, V., Somayajulu, Y. K., Sudhakar, M., and PANDEY, P. C., 2005, Oceanic front along $45^{\circ}$ east across Antarctic circumpolar current during Austral summer 2004: Current Science, v. 88, p 1669-1673.

, Luis, A. J., Somayajulu, Y. K, Babu, V. R., Dash, M. K., PedneKar, S. M., Babu, K. N., Sudharkar, M., and PANDEY, P. C., 2006, Fronts, water masses and heat content variability in the western Indian sector of Southern Ocean during austral summer 2004: Journal of Marine System, v. 63 , p. 20-34.

Bé, A. W. H., and Tolderlund, D. S., 1971, Distribution and ecology of living planktonic foraminifera in surface waters of the Atlantic and Indian Ocean, in Funnel B.M., and Riedel, W. R. (eds.), The Micropaleontology of Oceans, p. 105-149.

Bemis, B. E., SPero, H. J., Bijma, J., and LeA, D. W., 1998, Reevaluation of the oxygen isotopic composition of planktonic foraminifera: experimental results and revised paleotemperature equations: Paleoceanography, v. 13, p. 150-160. 
$\longrightarrow,-$ LEA, D. W., and BIJMA, J., 2000, Temperature influence on the carbon isotopic composition of Globigerina bulloides and Orbulina universa (planktonic foraminifera): Marine Micropaleontology, v. 38, p. 213-228.

THUNELL R. C., 2002, Using species-specific paleotemperature equations with Foraminifera: A case study in the Southern California Bight: Marine Micropaleontology, v. 46, p. 405-430.

BiJMA, J., SPERO, H. J., and LEA, D. W., 1999, Reassessing foraminiferal stable isotope geochemistry: Impact of the oceanic carbonate system (experimental results), in Fischer, G., Wefer, G. (eds.), Use of Proxies in Paleoceanography, Examples from the South Atlantic: Springer, Berlin, p. 489512 .

CAYRE, O., and BASSINOT, F., 1998, Oxygen isotope composition of planktonic foraminiferal shells over the Indian Ocean: calibration to modern oceanographic data: Mineralogical Magazine, v. 62A, p. $288-289$.

Chen, M. T., Ho, H.-W., LaI, T.-D., Zheng, L., Miao, Q., Shea, K.-S., Chen, M.-P., Wang, P., Wei, K.-Y., and HuANG, C.-Y., 1998, Recent planktonic foraminifers and their relationships to surface ocean hydrography of the South China Sea: Marine Geology, v. 146, p. 173-190.

ConAN, S. M. H., and BRUMMER, G.-J., 2000, Fluxes of planktic foraminifera in response to monsoonal upwelling on the Somalia Basin margin: Deep-Sea Research, Part 2, v. 47, p. 2207-2227.

Colborn, J. G., 1975, The Thermal Structure of the Indian Ocean: The University Press of Hawaii, Honolulu, $173 \mathrm{p}$.

Deuser, W. G., Ross, E. H., Hemleben, C., and Spindler, M., 1981, Seasonal changes in species composition, numbers, mass, size, and isotopic composition of planktonic foraminifera settling into the deep Sargasso Sea: Palaeogeography, Palaeoclimatology, Palaeoecology, v. 33, p. 103127.

DURAZZI, J. T., 1981, Stable-isotope studies of planktonic foraminifera in North Atlantic core tops: Palaeogeography, Palaeoclimatology, Palaeoecology, v. 33, p. 157-172.

Epstein, S., Buchsbaum, R., Lowenstam, H. A., and Urey, H. C., 1953, Revised carbonate-water isotopic temperature scale: Geological Society of America Bulletin, v. 64, p. 1315-1326.

FINE, R. A., 1985, Direct evidence using tritium data for the throughflow from the Pacific to the Indian Ocean: Nature, v. 315 , p. $478-480$.

Fine, R. A., Smethie, W. M., Bullister, J. L., Rheind, M., Min, D. H., WARner, M. J., Poisson, A., and WeISS, R. F., 2008, Decadal ventilation and mixing of Indian Ocean waters: Deep Sea Research Part I: Oceanographic Research Papers, v. 55, p. 20-37.

GuptA, A. K., ANDERson, D. M., and OverPeCK, J. T., 2003, Abrupt changes in the Asian southwest monsoon during the Holocene and their links to the North Atlantic Ocean: Nature, v. 421, p. 354 357. 
Grundlingh, M. L., Carter, R. A., and Stanton, R. C., 1991, Circulation and water properties of the Southwest Indian Ocean: Progress in Oceanography, v. 28, p. 305-342.

HemleBen, C., and BijMA, J., 1994, Foraminiferal population dynamics, stable isotopes and paleoenvironment in the Red Sea and the North Atlantic, in Zahn, R., Kaminski, M., Labeyrie, L., and Pedersen T. (eds.), Carbon cycling in the glacial ocean Constraints on the ocean's role in global change: NATO ASI Series-I, no. 17, p. 145-166.

KAHN, M. I., and WiLliAMS, D. F., 1981, Oxygen and carbon isotopic composition of living planktonic foraminifera from the northeast Pacific Ocean: Palaeogeography, Palaeoclimatology, Palaeoecology, v. 33, p. 47-69.

Khare, N., and ChatURVEDI, S. K., 2006, Size variations of planktonic foraminiferal population in the Indian Ocean sector of Southern Ocean: Indian Journal of Marine Sciences, v. 35, p. 221-226.

KIM, S.-T., and O'NEIL, J. R., 1997, Equilibrium and non-equilibrium oxygen isotope effects in synthetic carbonates: Geochimica et Cosmochimica Acta, v. 61, p. 3461-3475.

KING, A. L., and HowARD, W. R., 2005, $\delta^{18}$ O seasonality of planktonic foraminifera from Southern Ocean sediment traps: Latitudinal gradients and implications for paleoclimate reconstructions: Marine Micropaleontology, v. 56, p. 1-24.

Kopczynska, E. E., Dehairs, F., Elskens, M., and Wright, S., 2001, Phytoplankton and microzooplankton variability between the Subtropical and Polar fronts south of Australia: thriving under regenerative and new production in late summer: Journal of Geophysical Research, v. 106, p. 31597-31609.

Levitus, S., and Boyer, T. P., 1994, NOAA Atlas NESDIS 4; World Ocean Atlas v. 4. Temperature, U.S. Government Printing Office, Washington, D.C., 117 p.

Mortyn, P. G., and Charles, C. D., 2003, Planktonic foraminiferal depth habitat and $\delta 180$ calibrations: Plankton tow results from the Atlantic sector of the Southern Ocean: Paleoceanography, v. 18, 1037, doi:10.1029/2001PA000637.

Mulitza, S., Boltovskoy, D., Donner, B., Meggers, H., PAul, A., and Wefer, G., 2003, Temperature: $\delta^{18} \mathrm{O}$ relationships of planktonic foraminifera collected from surface waters: Palaeogeography, Palaeoclimatology, Palaeoecology, v. 202, p. 143-152.

NAidu, P. D., and MALmGren, B. J., 1996, A high resolution record of late Quaternary upwelling along the Oman margin, Arabian Sea based on planktonic foraminifera: Paleoceanography, v. 11, p. $129-140$.

Peeters, F. J. C., Brummer, G.-J. A., and Ganssen, G., 2002, The effect of upwelling on the distribution and stable isotope composition of Globigerina bulloides and Globigerinoides ruber (planktic foraminifera) in modern surface waters of the NW Arabian Sea: Global and Planetary Change, v. 34, p. 269-291. 
Prell, W. L., 1984, Climate Processes and Climate Sensitivity in Hansen, J. E., and Takahashi, T. (eds.), Title of Book: American Geophysical Union, Washington, D.C., p. 48-57.

RAO, R. R., MolinaRI, R. L., and FESTA, J. F., 1989, Evolution of the climatological near-surface thermal structure of the tropical Indian Ocean: 1. Description of mean monthly mixed layer depth, and sea surface temperature, surface current, and surface meteorological fields: Journal of Geophysical Research, v. 94, p. 10801-10815.

SAUtTer, L. R., and Thunell, R. C., 1991, Seasonal variability in the $\delta^{18} \mathrm{O}$ and $\delta^{13} \mathrm{C}$ of planktonic foraminifera from an upwelling environment: Sediment trap results from the San Pedro basin, Southern California Bight: Paleoceanography, v. 6, p. 307-334.

Sen GuptA, B. K., 1991, Modern Foraminifera: Kluwer Academic Publishers, Dordrecht, 371p.

SchmidT, G. A., BigG, G. R., and Rohling, E. J., 1999, Global Seawater Oxygen-18 Database, http://data.giss.nasa.gov/o18data/.

Schott, F. A., and MCCREARY, JR., J. P., 2001, The monsoon circulation of the Indian Ocean: Progress in Oceanography, v. 51, 1-123.

SPERO, H. J., and LEA, D. W., 1996, Experimental determination of stable isotope variability in Globigerina bulloides: implications for paleoceanographic reconstructions: Marine Micropaleontology, v. 28, p. 231-246.

Stramma, L., 1992, The South Indian Ocean Current: Journal of Physical Oceanography, v. 22, p. 325347.

Swallow, J. C., FieuX, M., and SchotT, F., 1988, The boundary currents east and north of Madagascar, Part I: Geostrophic currents and transports: Journal of Geophysical Research, v. 93, p. 4951-4962.

TOMCZAK, M., and Godfrey, J. S., 2003, Regional Oceanography: An Introduction: $2^{\text {nd }}$ Edn.: Publisher?, City?, 390 p.

Toole, J. M., and WArren, B. A., 1993, A hydrographic section across the subtropical south Indian Ocean: Deep Sea Research, v. 40, p.1973-2019.

Waelbroeck, C., Mulitza, S., Spero, H., Dokken, T., Kiefer, T., and Cortijo, E., 2005, A global compilation of late Holocene planktonic foraminiferal $\delta^{18} \mathrm{O}$ : relationship between surface water temperature and $\delta^{18} \mathrm{O}$ : Quaternary Science Reviews, v. 24, p. 853-868.

Williams, D. F., and HeAly-WiLliams, N., 1980, Oxygen isotopic-hydrographic relationships among Recent planktonic Foraminifera from the Indian Ocean: Nature, v. 283, p. 848-852.

WYRTKI, K., 1971, Oceanographic atlas of the international Indian Ocean expedition: National Science Foundation, Washington, D.C., pages?

You, Y., and TOMCZAK, M., 1993, Thermocline circulation and ventilation in the Indian Ocean derived from water mass analysis: Deep-Sea Research, v. 40, p. 13-56. 
Table 1 Details, including location, water depth and $\delta^{18} \mathrm{O}$ Globigerina bulloides of all the samples.

Table 2 Relationship between $\delta^{18}$ Osw and seawater salinity between different latitudinal zones, derived from the regression equation.

Table 3 Different paleotemperature equations used to calculate seawater temperature from the $\delta^{18}$ Osw and $\delta^{18}$ Oc. 
FIGURE 1 Location of the sediment samples used in this study from the southwestern Indian Ocean sites, along with the major oceanographic fronts in the area.

FIGURE 2. Locations used to develop regression equation between oxygen isotopic composition of the seawater and salinity in the southwestern Indian Ocean (Source: Schmidt and others, 1999).

FIGURE 3. Graph shows the relationship between seawater oxygen isotopic composition and salinity in the southwestern Indian Ocean, used to calculate $\delta^{18} \mathrm{Osw}$, at different latitudes. The regression equations between $0-10^{\circ} \mathrm{S}$ (Fig. 3A), 10-20 $\mathrm{S}$ (Fig. 3B) and $20-30^{\circ} \mathrm{S}$ (Fig. 3C) latitudes are comparable. Therefore the equation based on the plot of all the data points between $0-30^{\circ} \mathrm{S}$ latitudes (Fig. 3D) was used for the sample locations falling between $0-30^{\circ} \mathrm{S}$ latitude. However the relationship was different between $30-40^{\circ} \mathrm{S}$ (Fig. 3E) and $40-50^{\circ} \mathrm{S}$ latitudes (Fig. 3F).

FIGURE 4. Comparison between seawater temperature estimated using shell $\delta^{18} \mathrm{O}$ from G. bulloides by different paleotemperature equations and the CTD measured and Levitus seawater temperature at different water depths. (A) at $0 \mathrm{~m},(\mathrm{~B})$ at $50 \mathrm{~m},(\mathrm{C})$ at $75 \mathrm{~m},(\mathrm{D})$ at $100 \mathrm{~m},(\mathrm{E})$ at $150 \mathrm{~m}$ and (F) at $200 \mathrm{~m}$.

FIGURE 5 Seawater salinity estimated using $\delta^{18} \mathrm{O}$ shell calcite from G. bulloides compared with the CTD measured and Levitus seawater salinity over 0-200 m water depth. (A) at $0 \mathrm{~m},(\mathrm{~B})$ at $50 \mathrm{~m},(\mathrm{C})$ at $75 \mathrm{~m},(\mathrm{D})$ at $100 \mathrm{~m},(\mathrm{E})$ at $150 \mathrm{~m}$, and (F) at $200 \mathrm{~m}$.

Figure 6. The comparison of estimated seawater temperature with the seasonal seawater temperature at different water depths. 
R. Saraswat, Table 1

\begin{tabular}{|c|c|c|c|c|c|}
\hline Sr. No. & Sample No. & $\begin{array}{l}\text { Latitude } \\
\left({ }^{\circ} \mathrm{S}\right)\end{array}$ & $\begin{array}{c}\text { Longitude } \\
\left({ }^{\circ} \mathrm{E}\right)\end{array}$ & $\begin{array}{l}\text { Water Depth } \\
\quad(\mathrm{m})\end{array}$ & $\begin{array}{c}\delta^{18} \mathrm{O} \text { G. bulloides } \\
(\% \mathrm{\%})\end{array}$ \\
\hline 1 & SK199C/10 & 1.92 & 67.88 & 2597 & -1.09 \\
\hline 2 & SK199C/12 & 4.67 & 67.10 & 3320 & -0.74 \\
\hline 3 & SK199C/13 & -7.36 & 67.17 & 3305 & -1.11 \\
\hline 4 & SK199C/14 & -9.18 & 65.96 & 3373 & -1.53 \\
\hline 5 & SK199C/15 & -11.42 & 67.40 & 3513 & -0.98 \\
\hline 6 & SK199C/16 & -12.59 & 67.14 & 3722 & -1.09 \\
\hline 7 & SK199C/17 & -15.28 & 66.01 & 3368 & -1.35 \\
\hline 8 & SK199C/19 & -16.27 & 63.46 & 4003 & -0.02 \\
\hline 9 & SK200/05 & -28.32 & 48.73 & 2295 & 0.63 \\
\hline 10 & SK200/09 & -30.91 & 44.86 & 2227 & -0.04 \\
\hline 11 & SK200/14 & -36.13 & 44.89 & 2805 & 0.88 \\
\hline 12 & SK200/15 & -37.00 & 44.98 & 2984 & 0.45 \\
\hline 13 & SK200/17 & -39.02 & 44.97 & 4022 & 1.13 \\
\hline 14 & SK200/19 & -40.98 & 45.06 & 2532 & 2.82 \\
\hline 15 & SK200/21 & -43.15 & 44.98 & 3210 & 1.71 \\
\hline 16 & SK200/22A & -43.69 & 45.07 & 2723 & 1.96 \\
\hline 17 & SK200/23 & -45.00 & 45.01 & 1423 & 2.49 \\
\hline 18 & SK200/27 & -49.01 & 45.22 & 4377 & 2.94 \\
\hline 19 & SK200/33 & -55.01 & 45.01 & 4185 & 3.13 \\
\hline
\end{tabular}


R. Saraswat, Table 2

\begin{tabular}{clcc}
$\#$ & Equation & Latitude & Fig. 3 \\
\hline 1 & $\delta^{18}$ Osw $=0.22 \times$ Salinity -7.38 & $0-10^{\circ} \mathrm{S}$ & $\mathrm{A}$ \\
2 & $\delta^{18}$ Osw $=0.20 \times$ Salinity -6.75 & $10-20^{\circ} \mathrm{S}$ & $\mathrm{B}$ \\
3 & $\delta^{18}$ Osw $=0.24 \times$ Salinity -7.88 & $20-30^{\circ} \mathrm{S}$ & $\mathrm{C}$ \\
4 & $\delta^{18}$ Osw $=0.26 \times$ Salinity -8.51 & $0-30^{\circ} \mathrm{S}$ & $\mathrm{D}$ \\
5 & $\delta^{18}$ Osw $=-0.28 \times$ Salinity +10.19 & $30-40^{\circ} \mathrm{S}$ & $\mathrm{E}$ \\
6 & $\delta^{18}$ Osw $=0.62 \times$ Salinity -21.41 & $40-50^{\circ} \mathrm{S}$ & $\mathrm{F}$
\end{tabular}


R. Saraswat, Table 3

\begin{tabular}{l|ll}
$\#$ & Equation & Source \\
\hline 1 & $\mathrm{~T}=13.2-4.89 \times\left(\delta^{18} \mathrm{Oc}-\delta^{18} \mathrm{Osw}\right)$ & Bemis \& others, 1998 \\
2 & $\mathrm{~T}=13.4-4.48 \times\left(\delta^{18} \mathrm{Oc}-\delta^{18} \mathrm{Osw}\right)$ & Bemis \& others, 2002 \\
3 & $\mathrm{~T}=16.5 \varepsilon 4.3 \times\left(\delta^{18} \mathrm{Oc}-\delta^{18} \mathrm{Osw}\right)+0.14 \times\left(\delta^{18} \mathrm{Oc}-\delta^{18} \mathrm{Osw}\right)^{2}$ & Epstein \& others, 1953 \\
4 & $\mathrm{~T}=16.1-4.64 \times\left(\delta^{18} \mathrm{Oc}-\delta^{18} \mathrm{Osw}\right)+0.09 \times\left(\delta^{18} \mathrm{Oc}-\delta^{18} \mathrm{Osw}\right)^{2}$ & Kim and O’Neil, 1997
\end{tabular}




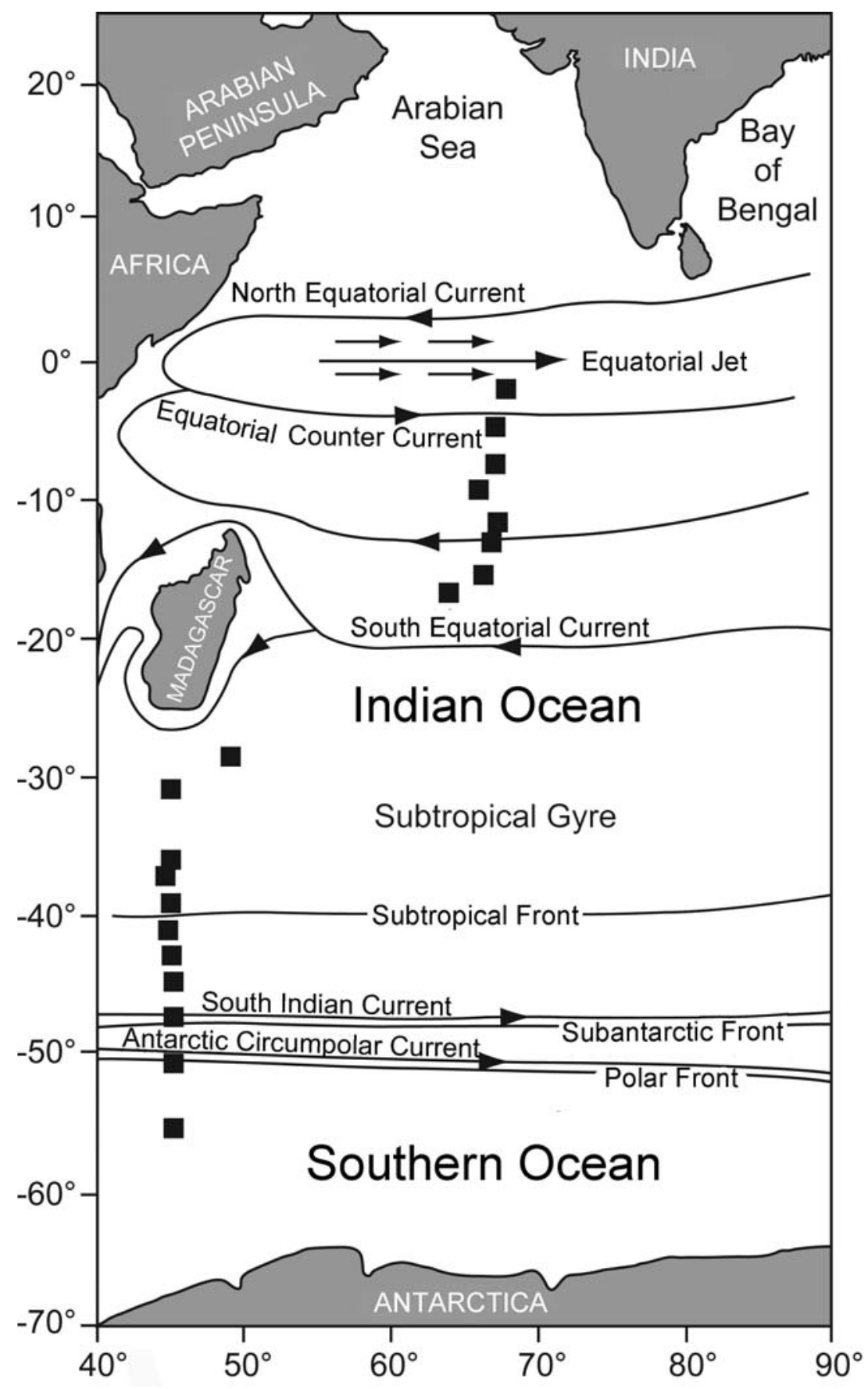




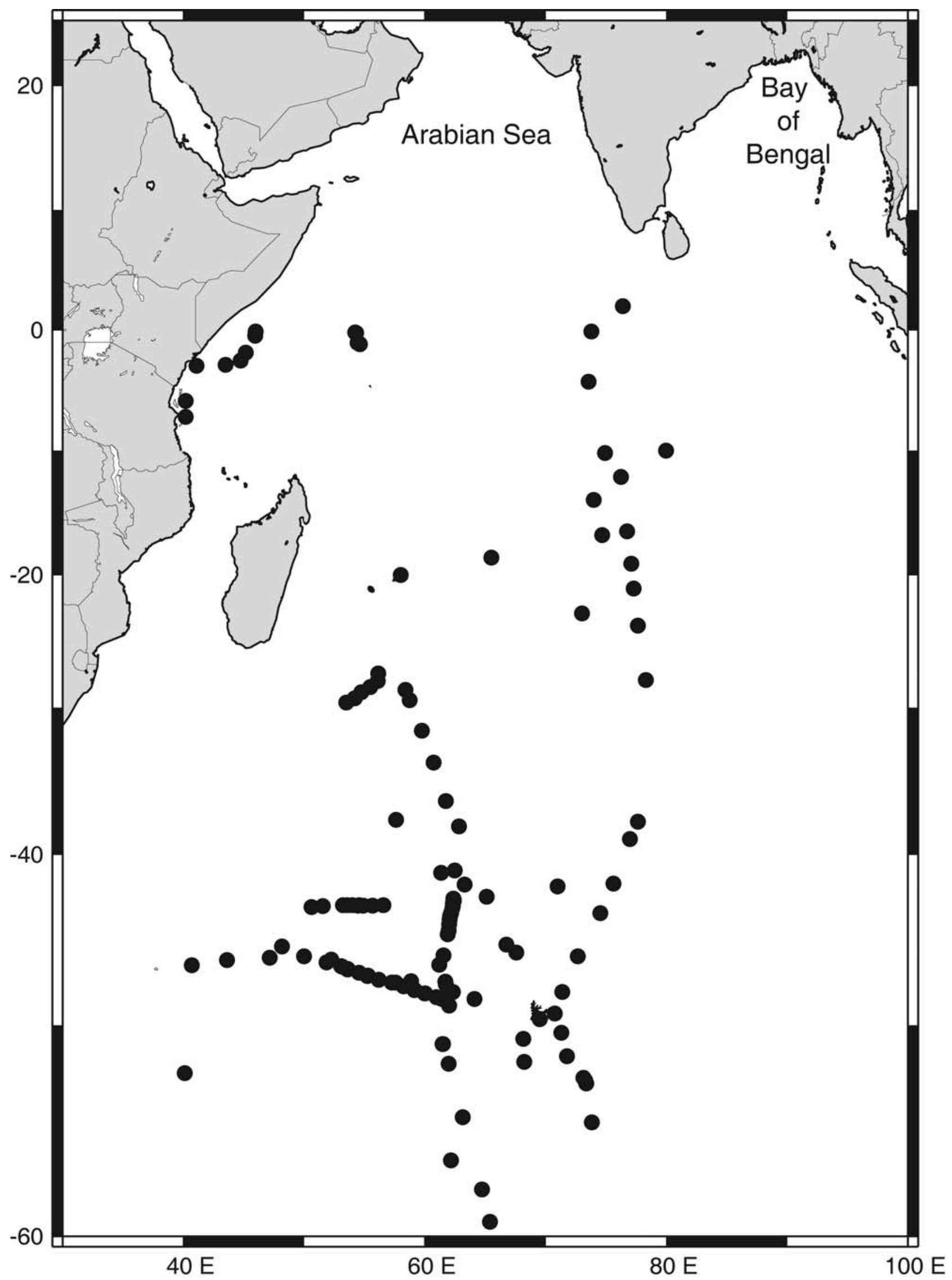



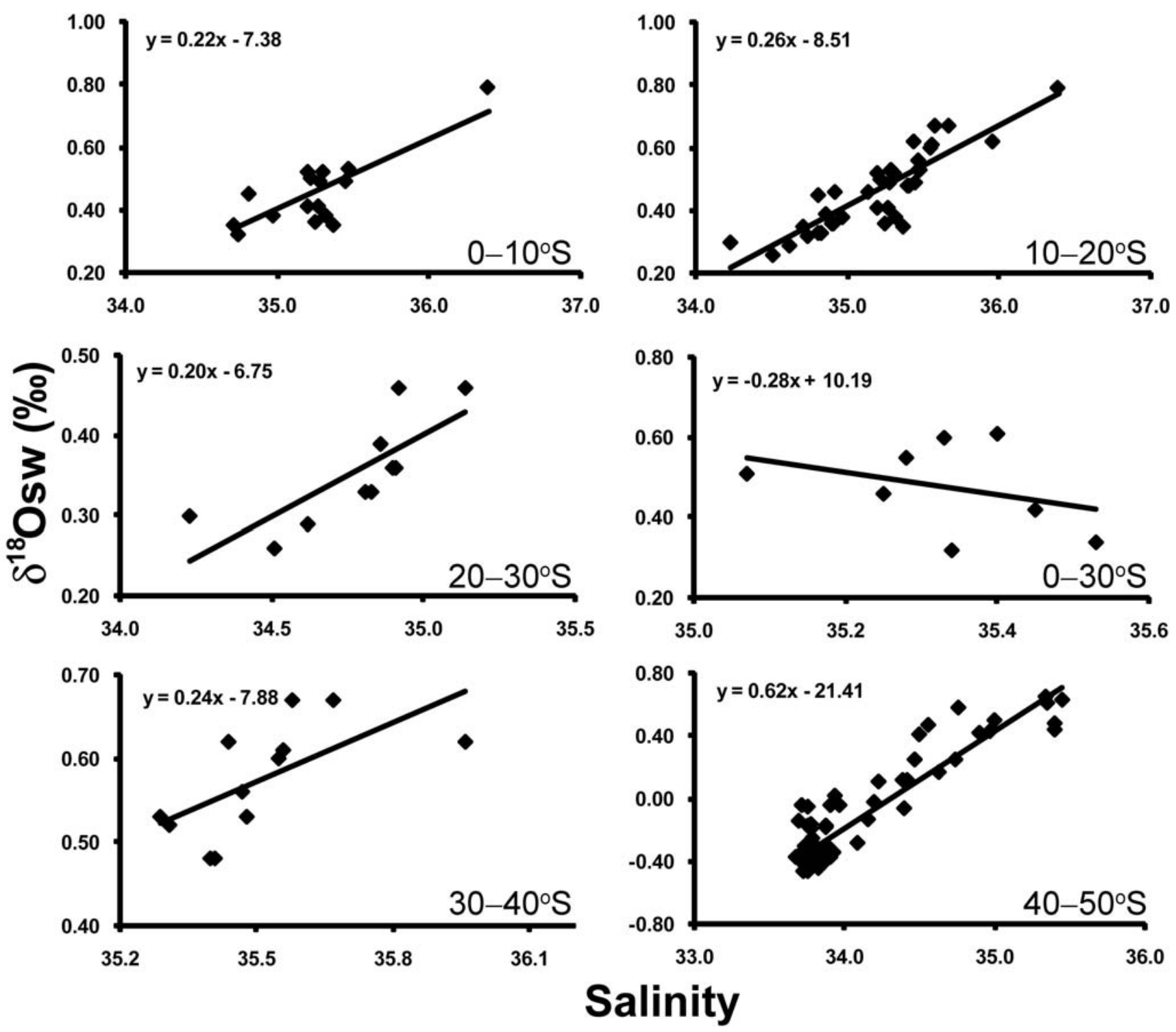


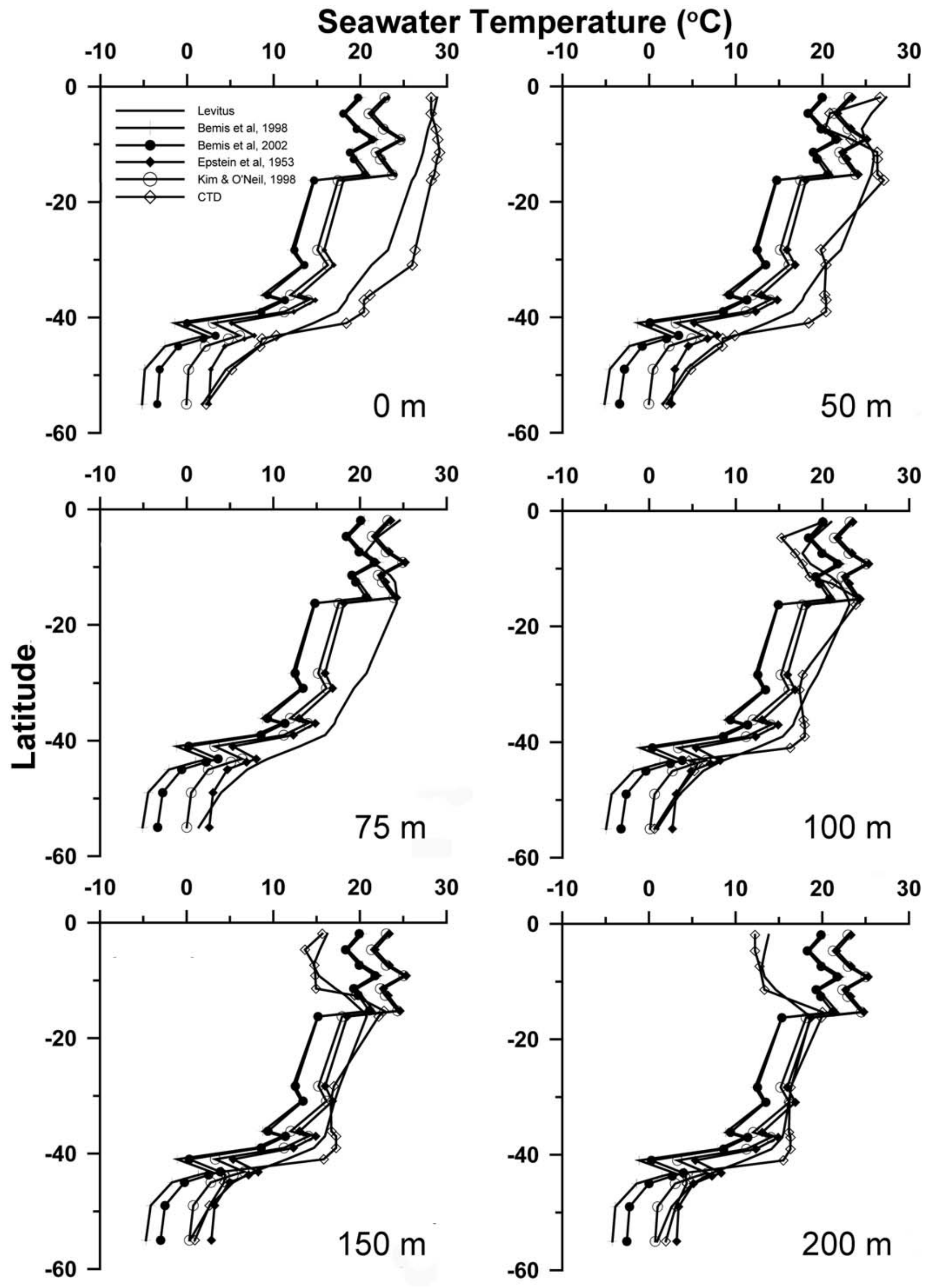




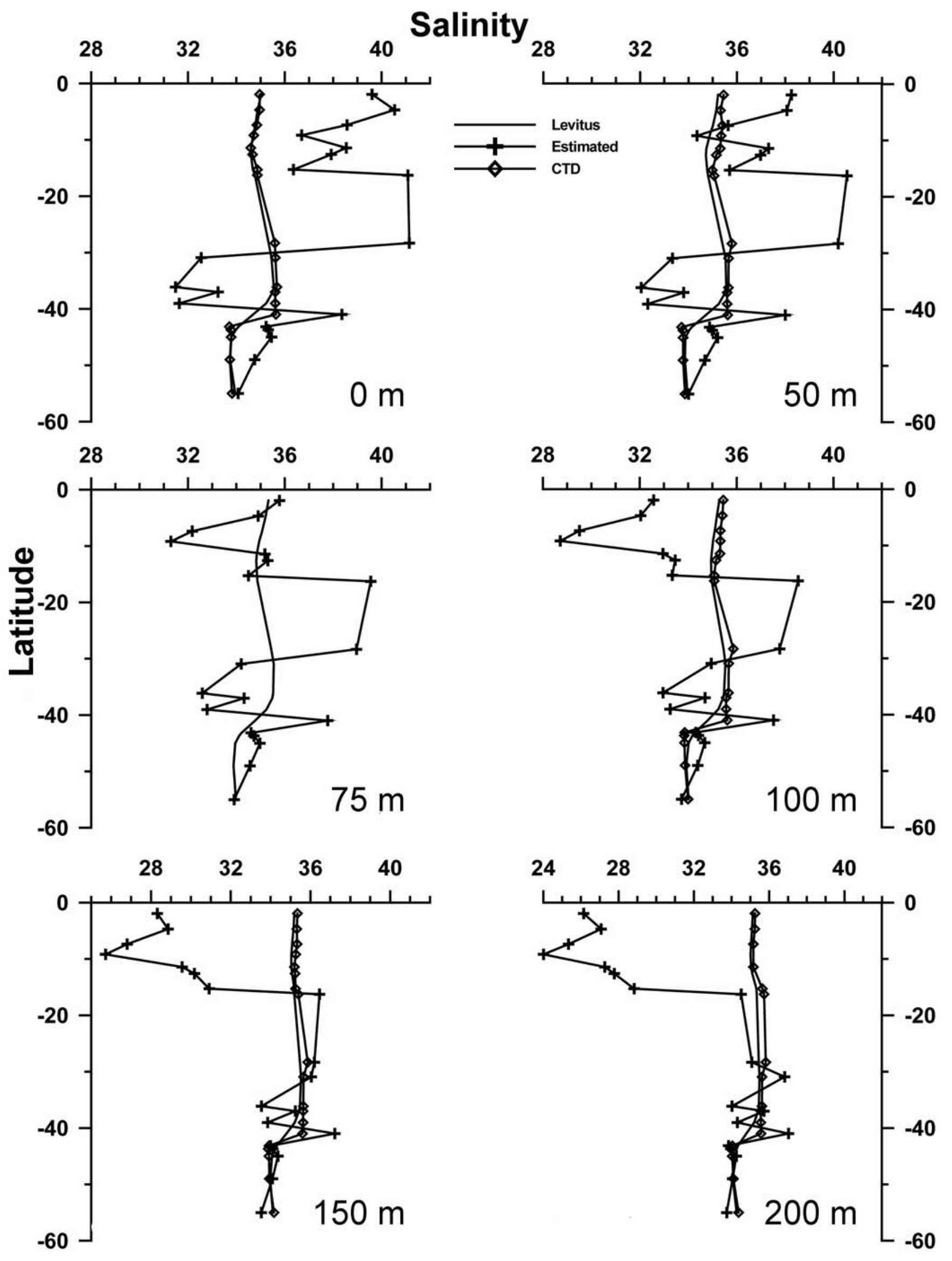




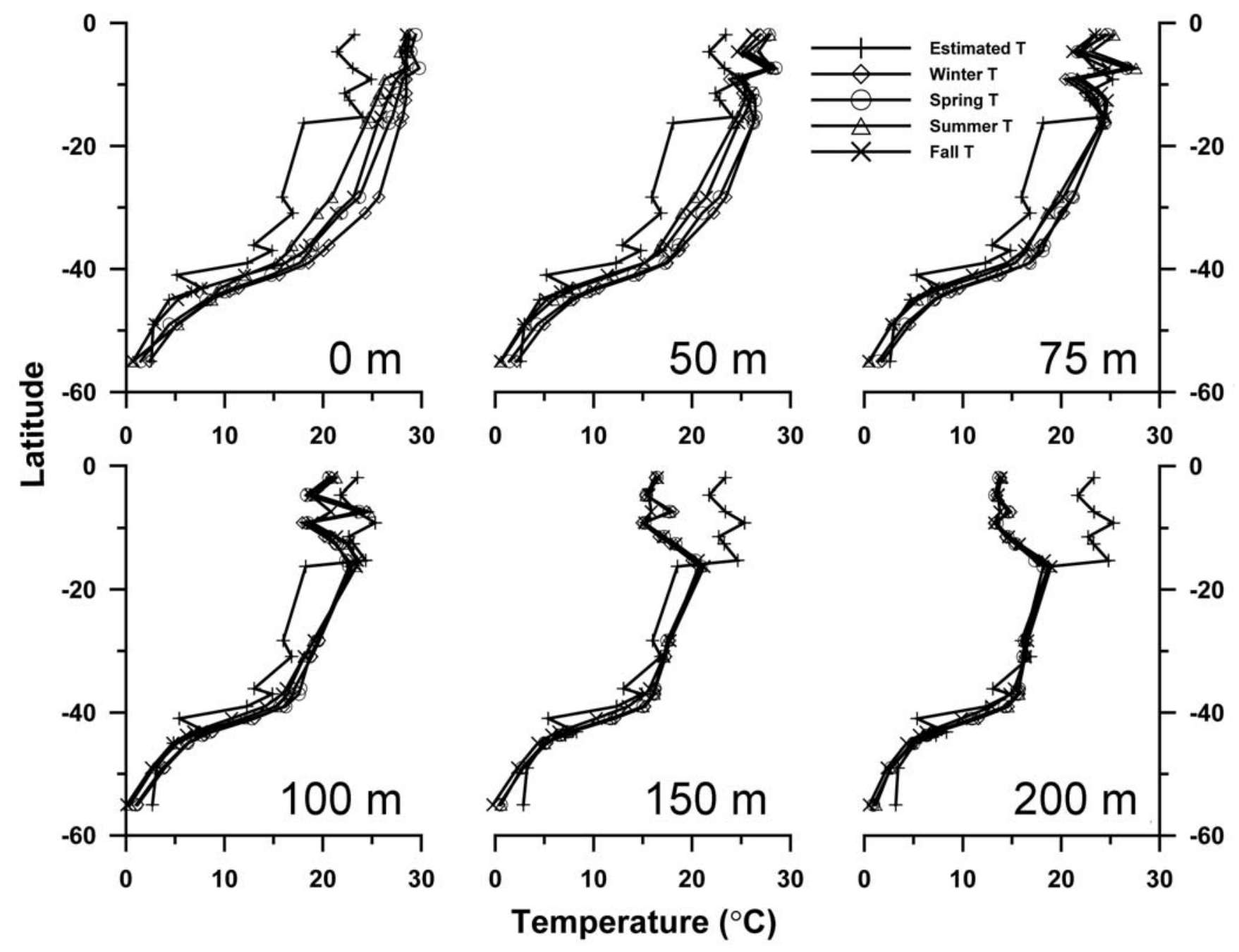

